\title{
REVITALIZATION PROJECT MANAGEMENT: A CASE STUDY IN THE CAMPOS ELÍSIOS SET SQUARE
}

\author{
Sebastião Theoto Ramos Corrêa ${ }^{1}$, David Barbosa de Alencar ${ }^{2}$, Camily Murrieta Vasconcelos \\ Oliveira Bezerra ${ }^{3}$ and Cleuson de Menezes Atayde ${ }^{4}$
}

\author{
${ }^{1,2}$ Blauro Cardoso de Mattos Higher Education Institute - FASERRA. Manaus-Amazonas, Brazil. \\ 3 Nilton Lins University. Manaus-Amazonas, Brazil.
}

Email: stheoto@ hotmail.com, david002870@ hotmail.com, camilymv@hotmail.com, cleuson_cma@hotmail.com

Received: Aug $19^{\text {th }}, 2019$

Accepted: Aug $30^{\text {th }}, 2019$

Published: December 02 ${ }^{\text {th }}, 2019$

Copyright @2016 by authors and Galileo Institute of Technology and Education of the Amazon (ITEGAM).

This work is licensed under the Creative Commons Attribution International License (CC BY 4.0).

https://creativecommons.org/licen ses/by/4.0/

\section{Opea Acten}

\begin{abstract}
Regarding the historic squares of the city, several have reached a stage of total degradation others have disappeared or suffer from overuse or misuse. Methodology: bibliographic and field research. Revitalization deals with a series of steps that lead a given space to have new efficiency, a new sense of usability, improving its surroundings in order to provide its residents and visitors a better living and leisure space. The proposal has a modern architecture following the standards of reforms that are currently being made in all major cities of the country, among its modifications include the implementation of outdoor gym, playground, ramps designed within accessibility standards, tactile floor installation, etc. The cost of the project will be R \$ $255,837.02$ plus BDI rate of $23.89 \%$, lasting 60 days for its completion.
\end{abstract}

Keywords: Revitalization proposal; Square; Projects.

\section{INTRODUTION}

Throughout history, the squares have always served as a meeting place for city dwellers, true public spaces for coexistence. The beauty of a square is constituted from its history, its landscape design and its urban design.

The integration between morphology, aesthetics and appropriation is what allows the formation of squares, such as symbolic spaces, places of memory, soul of the city. This is how we can understand the sentence above, because, in antiquity, cities were formed from their living spaces. To belong to the city, to be a citizen, to inhabit the meeting places, to share the worship, to attend the assemblies, to attend the parties, to accompany the processions, to experience the spaces, participating in public life. The square symbolized the city itself, as it was in this space that daily activities were developed[1].

A well-structured square, with attractive new urban furniture, adequate living space and accessibility, increases its usability for its residents, increases its share of visitors and makes its region an attractive for entrepreneurs to expand or start new businesses, enriching their locality.
The term "revitalization" is used when an area (space) acquires a new function, where its main objective is to transform existing areas into an entertainment and leisure space in order to promote reforms in the physical structure of public facilities through the planning of new measures. Its main activity is the buildings that constitute historical heritage, squares, buildings, among other areas, underutilizing or replacing degraded or abandoned areas, through the process of recovering old uses and urbanistic or natural attributes.

In a brief analysis of the locality, it was noted that, although there is a large and public space, there is a lack of new and attractive environments for the community, the square in question has a basic profile with benches and sidewalks, it needs to be improved to the point of becoming a reference in and around the neighborhood.

The need for improvement led the project to be implemented in order to make Campos Elíseos Square a reference point in the region and create a significant increase in its use, consequently increasing the commercial number in its vicinity.

Given the above, the overall objective is to develop a revitalization proposal of the square of the Champs Elysees square so that it can contribute to relevant improvements for the local population. And as specific objectives: Reach the population with 
the construction of a free playground and outdoor gym on site; Make the square economically viable in the future, using as reference the squares of Avenida Nilton Lins and square of the Dom Pedro complex; Define a price breakdown table for project execution

The project aims not only to improve the Campos Elíseos Square, but also to serve as a starting point for innovating the existing square models in the neighborhood, creating something new for the region, refining the old one that can be reused, exposing urban innovations, improving thus the interaction between residents, bringing more security and new options for well-being and leisure for the community.

\section{B IBLIOGRAPHIC REVIEW}

\section{II.1 DEFINITIONS SQUARE}

The squares, over time, taking into account the various aspects that involve them, such as definition, functions, uses and conceptions, have undergone significant changes. However, it is agreed that, despite the changes imposed by time, the squares still represent a public space of great importance in urban daily life [2].

Its origin is linked to the agora of Greece-commercial, administrative and political centers of the ancient Greek polis, where were discussed issues important to the lives of citizens. The agoras, derived from the Roman Imperial Forum and the great piazze and squares of major European cities [3].

In Brazil, the squares began to appear around the churches. The most sumptuous residences, the most important public buildings, the main commercial establishments, were all built near these public places that also served as a link between the community and the parishes. In our country, the term square is more related to garden spaces, while for dry spaces - such as European piazze and plazas - it has been adopted to call them broad, courtyards or yards. According to [4], one of the first gardens to be built in Brazil was the Rio de Janeiro Public Promenade, designed by Valentim da Fonseca e Silva and inaugurated in 1783.

In Manaus, the first public square was located near the former Mother Church of Our Lady of Conception and the São José da Barra do Rio Negro Fortress, the initial landmark of the occupation of the City [5]. This area is currently part of the Centro neighborhood and is located near Governador Vitório, Viscount de Mauá, Tamandaré, Bernardo Ramos, Gabriel Salgado and 7 de September avenues. there was an indigenous cemetery. It was later called Largo da Trincheira, a name believed to refer to a trench - a narrow, long channel, dug into the ground - that existed in its vicinity. At that time, this street extended from the current Nove de Novembro Square to Dom Pedro II [6].

In the Barra do Rio Negro City Plan, of 1844, raised by Captain Lieutenant Raphael Lopes Anjo (Library of the Army / RJ), as [7] this space appears as Largo do Pelourinho, a name that was possibly attributed to him. that was why there was a pillory in that area: a pillar of stone or wood where criminals and slaves were bound and punished. From the second half of the nineteenth century, the terrain of this square began to be subdivided, resulting from this process, two squares that exist to this day and will be addressed later: Dom Pedro II and Nove de November. Another public place considered one of the oldest is Largo da Campina, whose records indicate its existence since the 1840s. It was named after its location in the then Campina neighborhood - later called São José - in the area today. comprised of the current Epaminondas Avenue and Padre Ghislandi, Luiz Antony and Dez de Julho streets in the Center [8].

\section{II.2 FIRST SQUARES OF MANAUS}

\section{II.2.1 NOVEMBER 15TH SQUARE}

It was formerly called the Empress's Square, and a 5ndo n was built there around 1857. It stretched from the Brazilian street to the Empress's gamboa or stream. President Adolfo Lacerda (later devised the construction of a new 5 ndo $\mathrm{n}$ and a 5ndo, between gamboa and the palace bridge. [9] The square was widened by Epaminondas de Mello in 1865, expropriating the block of houses next door. This same 5ndo n5nte ordered the restoration of the remaining wetlands, with land taken from the seminary courtyard, where a bank of Brazil branch is today.

In 1868 the square was completely grounded and, the following year, paved, for a total of over $800 \mathrm{~m}^{2}$, and was built the ramp of the empress's 5ndo. Subsequently, the 5ndo of the quay and the 5ndo n of Praça da Imperatriz were contracted, which was completed in 1871 .

In 1870, the first seedlings of imperial palm trees, sent from Rio de Janeiro, and which remained there for many years, were planted there 5ndo n São Vicente Island. At the top of the square was the building where in the future would operate store 22 paulista [10].

\section{II.2.2 OSWALDO CRUZ SQUARE}

One of the most beautiful postcards that ever existed in the city, but which succumbed to the "development" and the carelessness of the public administrators and the population itself, this street initially extended from the old Brazilian street, nowadays Avenue Sete de Setembro. to the banks of the Olaria stream - arm of the Espírito Santo stream - next to the old provincial brickyard, and is therefore called Largo da Olaria. In the Plan of Villas de Manáos and Ega, raised

in 1845 by Raphael Lopes Anjo, this space already appears with the name of Praça da

Joy [11]. With the beginning of the Olaria creek grounding in the 60's of the 19th century, an area formed in front of the new Nossa Senhora da Conceição Matrix that was being built - and bordering the Espírito Santo creek, Praça da Imperatriz in honor. to Mary of Bourbon Sicily and Braganza, wife of the emperor Dom Pedro II.

From then on, both Lararia da Olaria and the new landed area had the same nomenclature [12]. In 1870, seedlings of palm trees, imported from Pará, were planted in the stretch of the old Largo da Olaria. Two decades later, on November 11, 1890, the municipal superintendent José Carlos da Silva Teles, at the proposal of the intendant Pedro Guilherme Alves da Silva, changed the name of the whole street to Praça 15 de Novembro, in honor of the first anniversary of the Proclamation of the Republic. In order to enlarge the area and complement the beautification project of this square, Governor Eduardo Ribeiro sanctioned Law 36 of July 29, 1893, which authorized the expropriation of buildings located on the banks of the Negro River. grounding your area. between November 15th Square and then Tenreiro Aranha Square, now November Nine.

\section{II.3 SQUARES THAT HAVE ALREADY BEEN REVIEWED}

Billiards Park is an urban park located in Manaus, on the banks of the Mindú stream, with the limits of Djalma Batista and Constantino Nery avenues and the Mindú and Cachoeira streams. It was inaugurated on October 24, 2006, by the Manaus City Hall, the 
city's anniversary, with the objective of offering leisure to the population, while preserving the environment [13].

Revitalized in 2010, Saudade Square is the newest historic street to be returned to the people of Manaus. Built over 100 years ago, the square had undergone several interventions over the decades, being totally uncharacterized. For its revitalization, it was restored its original layout, where several lines, from all corners of the square, lead directly to the central monument of Terreiro Aranha, the first president of the Province of Amazonas, imposingly supported by a large marble altar adorned. with bronze shields [14].

Although relatively small, Praça da Saudade is an extremely pleasant place that, surrounded by trees and gardens displaying hundreds of yellow flowers, has become a popular spot in central Manaus. You can grab a quick bite at one of two on-site diners, or simply read a book sitting in one of its many benches. Besides that, for being located in an area with tall buildings, it is the best location in the city center to watch the sky during the evening.

Opposite the square is the building of Atletico Rio Negro Club, one of the state's soccer teams. On the site, about a hundred years ago, there was a cemetery, hence the popular name of the square.

\section{MATERIAL AND METHODS}

For a correct project implementation, it is necessary to follow specific standards conditions related to the materials that will be used and in the execution of the appropriate services.

For this project were consulted articles, monographs, projects, in addition to the following technical and regulatory standards; [15] ABNT NBR 6118/2014, [16] ABNT NBR 5682/2005, [17] ABNT NBR 5733, [18] ABNT NBR 12284, [19] ABNT NBR 1367 [ 20 ] ABNT NBR 9050/2004. There will be a need for an engineer to oversee the execution of the project, a contractor to organize the services to be performed without doubt during the work and guard 24 hours to ensure safety on the construction site and other employees in the progress of the project. Work.

The services described in the project must be performed by qualified and qualified professionals, strictly following each step described in the project, and the materials to be used need to be of excellent quality to achieve a good return on safety and durability of the project as a whole.

\section{APPLICATION OF STUDY (REVITALIZATION PROPOSALS)}

Stage where task sequence will be carried out, following the norms for a quality execution and within the proposed schedule.

\section{IV.1 PRELIMINARY SERVICES}

This item is intended to expose the initial activities required to begin project implementation. Some of them, such as temporary installations, demolition and demolition waste removal, land clearing, earthmoving (if leveling is necessary) and checking the surrounding conditions, as this is a work near homes. All services must be performed according to Brazilian NBRs and NRs regulatory standards.

\section{IV.1.1 INSTALLATION OF THE CONSTRUCTION SITE}

Construction site facilities must be in accordance with regulatory standard NR18 and Brazilian Standard NBR 12284, which deal with conditions in the workplace and living areas respectively.

- For the office, a container with toilet, dimensions of 2.20 in width, 2.50 in height and 6.20 in length will be used, made of steel sheets and coated for better thermal and acoustic comfort on the construction site.

- For the warehouse, a container with dimensions of 2.20 in width, 2.50 in height and 6.20 in length will be used, made of steel sheets and coated for better thermal and acoustic comfort on the construction site.

- For refectory, a container with dimensions of 2.20 in width, 2.50 in height and 6.20 in length will be used, made of steel sheets and coated for better thermal and acoustic comfort on the construction site.

- Provisional water installation, to meet the needs of the construction site, will basically be cold water and sewage. They should be requested from the competent bodies by the technical responsible, so that there are no interruptions in the supply of the work in progress.

- There is many equipment that use electric energy, with this affirmative the temporary installation of electric energy is necessary that meets the needs of the construction site. Table 1 exemplifies some equipment with their respective powers, which are commonly used in construction.

Table 1: Equipment power and supply system.

\begin{tabular}{|c|c|c|}
\hline Equipment & Power (hp) & System \\
\hline Winch & $7.5-15$ & Three phase \\
\hline Concrete mixer & 3.0 & Three phase \\
\hline Water pump & 3.0 & Three phase \\
\hline Electric saw & 2.0 & Three phase \\
\hline Cutting machine & 2.0 & Three phase \\
\hline Vibrator & 3.0 & Three phase \\
\hline \multicolumn{2}{|c}{ Source: [21]. }
\end{tabular}

- Installation of signpost, indicating details of the work and inscriptions provided by the inspection. The plate will have an area of approximately $10 \mathrm{~m}^{2}$, will be made of galvanized steel and installed in a space of good visibility and readable to the public.

- Plywood cladding of the order of $2.5 \mathrm{~m}$ and impact resistant minimum $60 \mathrm{kgf} / \mathrm{m}^{2}$ will be used to surround the site, will be installed on the road $0.50 \mathrm{~cm}$ from the curb, following the requirements of Regulatory Standard NR18.

Perimeter $=(26.28 \mathrm{~m}+5.40 \mathrm{~m}+52.76 \mathrm{~m}+4.02 \mathrm{~m}+27.58 \mathrm{~m})$
Perimeter $=116.04 \mathrm{~m}$ Area $=116.04 \times 2.20 \mathrm{~m} ;$ Area $=255.29 \mathrm{~m}^{2}$

\section{IV.1.2 MATERIAL REMOVAL AND DEMOLITION}

When there are constructions in the place where the work will be performed, it is possible to use part of the existing material. In some cases, nothing is reused, and needs demolition services.

NBR 5682 - "Contracting, Execution and Supervision of Demolitions" [ABNT, 1977], details some requirements for the contracting and licensing of demolition work, care that must be taken before, during and after the work and execution steps.

a) Removal of stacked and unmoved curb: Perimeter $=$ $3.13 \mathrm{~m}^{3}$.

b) Sidewalk demolition: Area $=500.97 \mathrm{~m}^{2}$.

c) Gutter removal: $\mathrm{A}=41.96 \mathrm{~m}^{2}$.

d) Grass removal on slabs: Volume $=894.02 \mathrm{~m}^{3}$. 
e) Removal of concrete benches $(3.0 \times 0.40 \times 0.15)$ : Total $=$ 7 units, with volume $=1.26 \mathrm{~m}^{3}$.

f) Post removal: Total $=1$ unit.

\section{IV.1.3 TRANSPORT OF MATERIALS}

Service responsible for the transportation of all material and debris resulting from the removal and demolition services, local and accumulative waste during the work, for the cleaning and preparation of the land, with Average Transport Distance (DMT) up to $30 \mathrm{~km}$, by tipper. $544.19 \mathrm{~m}^{3}$.

(a) Mechanized tipping truck loading: Volume =

\section{IV.2 SOIL SERVICES}

Earthmoving services can be understood as a set of excavation, loading, transporting, unloading, compacting and finishing operations carried out in order to move from natural terrain to new desired topographic conformation.

This item involves planning and organization that are essential to minimize environmental impacts. It defines where there will be excavations of slopes (slopes) and where landfills will be made, without margin for improvisation. Earthmoving should be organized so that volumes of mowing or digging are utilized on the ground itself, reducing boot-off.

\section{IV.2.1 OUTDOOR GYM}

a) Conventional leasing of the work by means of jig, whose total area is of $133,64 \mathrm{~m}^{2}$

b) Land preparation as; leveling and soil compaction.

\section{IV.2.2 PLAYGROUND}

a) Conventional leasing of the work through jig, whose total area is $99.70 \mathrm{~m}^{2}$

b) Land preparation as; leveling and soil compaction.

\section{IV.2.3 SIDEWALK}

a) Manual excavation of the area, up to a depth of 1.5 meters, using the $30 \mathrm{~kg}$ bundle to strongly apex the trench bottoms:

Volume $=500.97 \mathrm{~m}^{2} \times 0.08 \mathrm{~m}$

Volume $=40.08 \mathrm{~m}^{3}$ distance.

b) Layering of land in layers using a bulldozer, up to $30 \mathrm{~m}$

c) Trench bottom trimming with $30 \mathrm{~kg}$ bundle, in successive layers with a maximum height of $20 \mathrm{~cm}$, to avoid cracks and unevenness.

$$
\begin{aligned}
& \text { TOTAL }=500.97 \times 15 \% \\
& \text { Area }=75.14 \mathrm{~m}^{2}
\end{aligned}
$$

\section{IV4.3 INFRASTRUCTURE}

This item will deal with the set of elements responsible for supporting the structure and all the processes that will still be performed and equipment that will be installed.

\section{IV.3.1 OUTDOOR GYM}

Space that will be used to practice functional exercises / physical activities, with free equipment, installed to meet the need of residents for better conditions of well-being.

a) Concrete ballast Fck $=20 \mathrm{Mpa}$

Volume $=\mathrm{L}$ xbxe, where: $\mathrm{L}=$ Perimeter $=4 \times 14.804=$ $59.22 \mathrm{~m}$

Volume $=59.22 \times 0.40 \times 0.05$

Volume $=1.18 \mathrm{~m}^{3}$

b) Concrete block masonry with mortar, cement, lime and sand (1: 1/2: 8) and measuring $15 \times 20 \times 40 \mathrm{~cm}$. Area = $23.69 \mathrm{~m}^{2}$

$$
\begin{aligned}
\text { Area } & =0.40 \times 59.22 \\
\text { Area } & =23.69 \mathrm{~m}^{2}
\end{aligned}
$$

\section{IV.3.2 PLAYGROUND}

Space reserved for leisure, with free toys, installed to meet the need of residents for fun and leisure of their children and special people.

a) Concrete ballast Fck $=20 \mathrm{Mpa}$

Volume $=\mathrm{L}$ xbxe

Where: $\mathrm{L}=$ Perimeter $=4 \times 14.804=59.22 \mathrm{~m}$

Volume $=59.22 \times 0.40 \times 0.05$

Volume $=1.18 \mathrm{~m}^{3}$

b) Sand Ballast:

Volume $=\mathrm{V}_{\text {Excavation }}-\mathrm{V}_{\text {Ballast }}-\mathrm{V}_{\text {Masonry }}$

Volume $=32.87-1.18-23.69 \times 0.10$

Volume $=29.32 \mathrm{~m}^{3}$

\section{IV.3.3 SIDEWALK}

Existing pavement areas already paved will be removed in the demolition process. New implementations of sidewalks with structural blocks will be made, which will be settled on a layer of compacted sand in the area already signaled for its execution.

a) Sand Ballast: Volume $=459.36 \mathrm{~m}^{3}$

\section{IV.4 PAVING}

a) Preformed curb laying: Perimeter $=466.18 \mathrm{~m}$

b) interlocked block of concrete, type holland, $10 \mathrm{~cm}$, $20 \mathrm{Mpa}$ without pigment and dimensions $(9,8 \times 10,0 \times 19,8 \mathrm{~cm})$ : Area $=459.36 \mathrm{~m}^{2}$

c) Tactile alert and directional floor, according to Brazilian Standard NBR 9050/2004. It should be installed perpendicular to the direction of travel, in a color and texture contrasting with the rest of the adjacent floor: Perimeter $=197.47 \mathrm{~m}$.

d) Ramp for Special Needs Carriers ( PCD's ), as specified in [20]. Size $2 \mathrm{~m} \times 1 \mathrm{~m}$.

Total $=2$ units

\section{IV.5 FACILITIES AND APPARATUS}

\section{IV.5.1 FACILITIES}

a) Wooden bench with iron frame, concrete base, painted with enamel paint and varnish:

Total $=12$ units.

b) Steel structure trash can with 01 paper bin 50 liters.

Total $=12$ units 


\section{IV.5.1 APPLIANCES TO BE DEPLOYED AT THE OUTDOOR GYM}

Guiding board for outdoor fitness equipment;

Hybrid triceps machine;

Hybrid bike tower;

Triple walk simulator;

High bar;

Hybrid bench press;

Leg press ;

Hybrid biceps;

High row;

Hybrid shoulder wheel for 6 positions.

\section{IV.5.2 DEVICES TO BE IMPLANTED IN THE PLAYGROUND}

Iron carousel, 6 seater, painting with synthetic enamel, $\emptyset 1,50 \mathrm{~m}$ :

House with slide and climbing net:

Triple Seesaw:

Triple balance:

\section{IV.6 LIGHTING} and ballasts:

Petal lamp with 4 luminaires, 400w x 220v steam lamps

\section{IV.7 LANDSCAPE}

Grass Batter Plates:

Area $=590.45 \mathrm{~m}^{2}$

Regional tree supply with $\mathrm{h}=2.00 \mathrm{~m}$

\section{IV.8 FINAL SERVICES}

Final cleaning of the work: Area $=1,247.20 \mathrm{~m}^{2}$

\section{RESULTS AND DISCUSSIONS}

The proposed revitalizes ç will of the Campos Eliseos square is estimated at (US $\$ 255.837 .02$ ). Thus, it is a project to improve cond ESSONS the square, that is, the locals as well as, the nearby, will make use of an organized and revitalized site after the completion of the project.

The government and the city may carry out the project by dividing the costs for the execution as a whole. The project is essential for the place, as it is in a precarious situation and unable to be used by the residents.

The Campos Elísios square revitalization project will provide leisure and entertainment for the population, as others who have already gone through these processes, such as:

Thus, with the park and the square of longing, the square located in Campo Elísios, after its revitalization, will provide besides leisure, comfort for the population and pleasant moments with the family.

Children will also have their reserved spaces, with the installation of various equipment that will provide moments of entertainment and play among in locus children, as well as a safe fun.

With the support of the government and the city, the project has to be carried out, as well as implemented for the well-being of the population of Campos Elísios, so everyone wins with the implementation of the project, because it is a public space that needs revitalizations. and maintenance so that the population can enjoy the environment.

\section{CONCLUSION}

Understanding the importance of a public space where leisure activities, physical activities and culture can be performed is the great challenge faced in big cities, we show in our work that we have always had squares and gardens linked to the history of our city and its peak in the century. Past governors and emperors have always attached importance to this type of construction.

It is relatively understandable today that municipalities have other priorities or other problems that they think are more important to solve given the economic crisis and low municipal revenues.

The concern was all about how to demonstrate to the city and to the population that it is possible to do a revitalization using a low budget and bringing the community of Campos Elísio to discuss and propose their ideas and suggestions always with a view to improving the place.

\section{BIBLIOGRAPHICAL REFERENCES}

[1] Coulanges, Fustel de. A cidade antiga. São Paulo: Hemus, $1975,68-150$

[2] De Angelis, B. L. D; De Angelis Neto, G.; Barros, G. D. A.; Barros, R. D. A. Praças: história, usos e funções. Maringá: Eduem, 2005.

[3] Pinheiro, Maria Luiza Ugarte. A Cidade Sobre os Ombros: trabalho e conflito no porto de Manaus, 1899-1925. Governo do Estado do Amazonas, Secretaria de Estado da Cultura, 2003.

[4] Martins, Marcio, et al. História natural e ecologia de uma taxocenose de serpentes de mata na região de Manaus, Amazônia Central, Brasil. 1994.

[5] Costa, Graciete Guerra da. Manaus: um estudo de seu patrimônio arquitetônico e urbano. 2013.

[6] Seráfico, José; Seráfico, Marcelo. A Zona Franca de Manaus e o capitalismo no Brasil. Estudos avançados, 2005, 19.54: 99-113.

[7] De Mesquita, Otoni Moreira. Manaus: história e arquitetura, 1852-1910. Editora Valer, 2006.

[8] Souza, Leno José Barata, et al. Cidade flutuante: uma Manaus sobre as águas (1920-1967). 2010.

[9] Hatoum, Milton. Escrever à margem da história. FronteiraZ. Revista do Programa de Estudos Pós-Graduados em Literatura e Crítica Literária, 2008, 2.

[10] Souza, Leno José Barata, et al. Vivência popular na imprensa amazonense: Manaus da borracha (1908-1917). 2005.

[11] Pinheiro, Valeria Cristina Soares; Tadei, Wanderli Pedro. Frequency, diversity, and productivity study on the Aedes aegypti most preferred containers in the city of Manaus, Amazonas, Brazil. Revista do Instituto de Medicina Tropical de São Paulo, 2002, 44.5: 245-250. 
[12] Duarte, Durango. Manaus: entre o passado e o presente. Mídia Ponto Comm, 2009.

[13] Filippini, Elizabeth. Patrimônio histórico-cultural em revisão: Revitalização do centro antigo de Manaus. 2008.

[14] Santos, Adrielly Vaz dos, et al. Praça da matriz: imagem, memória e sociabilidade. 2015.

[15] ABNT - Associaçao Brasileira De Normas Técnicas -. NBR6118: Projeto de Estruturas de Concreto - Procedimentos. Rio de Janeiro, 2014.

[16] (ABNT). NBR-5682: Contratação, Supervisão e execução de Demoliçoes. Rio de Janeiro, 1977.

[17] (ABNT). NBR-5733: Cimento Portland de alta resistência inicial. Rio de Janeiro, 1991.

[18] (ABNT). NBR-12284: Áreas de Convivência em canteiro de Obras. Rio de Janeiro, 1991.

[19] (ABNT). NBR-1367: Área de Vivencia em canteiro de Obra. Rio de Janeiro, 1991.

[20] (ABNT). NBR-9050: Acessibilidade, edificações, mobiliários, espaço e equipamentos urbanos. Rio de Janeiro, 2004.

[21] Lichtenstein, N. B.; Glezer, N. Curso O Processo de Construção Tradicional do Edifício. São Paulo, FDTE/EPUSP, 2012. 